\title{
Relationships between serum adiponectin and soluble TNF- $\alpha$ receptors and glucose and lipid oxidation in lean and obese subjects
}

\author{
A. Adamska - A. Nikołajuk - M. Karczewska-Kupczewska • \\ I. Kowalska $\cdot$ E. Otziomek $\cdot$ M. Górska $\cdot$ M. Strączkowski
}

Received: 1 October 2010/ Accepted: 20 December 2010/Published online: 15 January 2011

(C) The Author(s) 2011. This article is published with open access at Springerlink.com

\begin{abstract}
Insulin resistance might be associated with an impaired ability of insulin to stimulate glucose oxidation and inhibit lipid oxidation. Insulin action is also inversely associated with TNF- $\alpha$ system and positively related to adiponectin. The aim of the present study was to analyze the associations between serum adiponectin, soluble TNF- $\alpha$ receptors concentrations and the whole-body insulin sensitivity, lipid and glucose oxidation, non-oxidative glucose metabolism (NOGM) and metabolic flexibility in lean and obese subjects. We examined 53 subjects: 25 lean (BMI < $25 \mathrm{~kg} \times \mathrm{m}^{-2}$ ) and 28 with overweight or obesity (BMI > $25 \mathrm{~kg} \times \mathrm{m}^{-2}$ ) with normal glucose tolerance. Hyperinsulinemic euglycemic clamp and indirect calorimetry were performed. An increase in respiratory exchange ratio in response to insulin was used as a measure of metabolic flexibility. Obese subjects had lower insulin sensitivity, adiponectin and higher sTNFR1 (all $P<0.001$ ) and sTNFR2 $(P=0.001)$. Insulin sensitivity was positively related to adiponectin $(r=0.49, P<0.001)$ and negatively related to sTNFR $1(r=-0.40, P=0.004)$ and sTNFR2 $(r=-0.52, P<0.001)$. Adiponectin was related to the rate of glucose $(r=0.47, P<0.001)$ and lipid ( $r=-0.40, \quad P=0.003$ ) oxidation during the clamp, NOGM $(r=0.41, P=0.002)$ and metabolic flexibility $(r=0.36, P=0.007)$. Serum sTNFR1 and sTNFR2 were associated with the rate of glucose $(r=-0.45, P=0.001$; $r=-0.51, P<0.001$, respectively) and lipid $(r=0.52$,
\end{abstract}

A. Adamska - A. Nikołajuk - M. Karczewska-Kupczewska . I. Kowalska · E. Otziomek · M. Górska · M. Strączkowski ( $\square)$ Department of Endocrinology, Diabetology and Internal Medicine, Medical University of Białystok,

M.C. Sklodowskiej 24a, 15-276 Bialystok, Poland

e-mail: mstraczkowski@ poczta.onet.pl;

marek.straczkowski@umwb.edu.pl
$P<0.001 ; r=0.46, P=0.001$, respectively) oxidation during hyperinsulinemia, NOGM $(r=-0.31, P=0.02$; $r=-0.43, P=0.002$, respectively) and metabolic flexibility $(r=-0.47$ and $r=-0.51$, respectively, both $P<0.001)$ in an opposite manner than adiponectin. Our data suggest that soluble TNF- $\alpha$ receptors and adiponectin have multiple effects on glucose and lipid metabolism in obesity.

Keywords Obesity $\cdot$ Adiponectin .

Soluble TNF- $\alpha$ receptors $\cdot$ Substrate oxidation

\section{Introduction}

It is generally agreed that decreased insulin sensitivity is an important component in the pathogenesis of obesity, type 2 diabetes, hyperuricemia, cardiovascular disease, hypertension and polycystic ovary syndrome [1, 2]. Insulin resistance might be associated with an impaired ability of insulin to stimulate glucose oxidation and inhibit lipid oxidation [3-5]. It might also be related to an impaired insulin-stimulated non-oxidative glucose metabolism (NOGM), which reflects the rate of glycogen synthesis, mainly in the skeletal muscle [6-8]. The balance between various cytokines plays an important role in modeling insulin action, which is inversely associated with circulating pro-inflammatory cytokines like TNF- $\alpha$ [9-14] and positively related to anti-inflammatory adipocytokines like adiponectin [15-19]. Adiponectin has protective effects against cardiovascular disease (CVD) [20]. Sheng-Chiang $\mathrm{Su}$ et al. recently showed that adiponectin was significantly correlated with HOMA-IR and BMI might be the major determinant of plasma adiponectin and pro-inflammatory cytokines in young diabetes mellitus patients [20]. 
Adiponectin and $\mathrm{TNF}-\alpha$ could modulate the rates of substrates' metabolism. There is evidence that adiponectin has insulin-sensitizing properties $[16,18,21]$ and could be involved in glucose and lipid metabolism [5, 8, 22, 23]. It is less clear whether adiponectin is associated more with oxidative glucose or lipid metabolism during hyperinsulinemia $[5,22,24,25]$ or NOGM [8, 21, 22, 24, 26]. In experimental studies, recombinant adiponectin improved insulin sensitivity, mainly by increasing fatty acid oxidation [23]. Yin et al. showed that adiponectin can suppress lipid accumulation by promoting fatty acid oxidation during $\mathrm{C} 2 \mathrm{C} 12$ myogenesis, rather than fatty acid hydrolysis and synthesis [27]. Decreased adiponectin level is associated with decreased insulin-stimulated glucose uptake and oxidation [28].

Serum levels of soluble TNF- $\alpha$ receptors (sTNFR1 and sTNFR2) are supposed to reflect local tissue action of this cytokine $[10,29]$. There are conflicting data regarding the role of TNF- $\alpha$ in the control of substrate utilization. TNF$\alpha$-stimulated lipolysis was accompanied by decrease in fatty acid oxidation in 3T3-L1 adipocytes [30]. Pellieux et al. showed that angiotensin II decreased fatty acid oxidation pathway in adult rat cardiomyocytes by generation of TNF- $\alpha$ [31]. On the other hand, new data showed that TNFRs play a physiological role to limit body weight and adiposity by modestly increasing metabolic rate and fatty acid oxidation, and they alter adipose tissue macrophages status [32]. Plomgaard et al. demonstrate that 4-h rhTNF- $\alpha$ infusion increases whole-body lipolysis, without enhancing skeletal muscle fat metabolism and without affecting basal glucose turnover [33]. However, data in a human cardiac cell model demonstrated that TNF- $\alpha$ reduces the expression of PGC- $1 \alpha$ (peroxisome proliferator-activated receptor coactivator $1 \alpha$ ) which resulted in an increase in glucose oxidation rate [34].

Precise measurement of insulin sensitivity is an important issue, and different methods are proposed [36]. There are also simple indices of insulin action, for instance IGFBs (insulin-like growth factor-binding proteins) [37]. However, euglycemic hyperinsulinemic clamp remains the "gold standard" in assessing insulin sensitivity in vivo.

The aim of the present study was to analyze the associations between serum adiponectin, sTNFR1 and sTNFR2 concentrations and the whole-body insulin sensitivity, lipid and glucose oxidation and NOGM by applying the euglycemic clamp technique and indirect calorimetry in lean and obese subjects.

\section{Methods and procedures}

We examined 53 subjects: 25 lean $\left(\mathrm{BMI}<25 \mathrm{~kg} \times \mathrm{m}^{-2}\right)$ and 12 subjects with overweight $\left(25 \mathrm{~kg} \times \mathrm{m}^{-2}>\right.$ BMI $<$ $\left.30 \mathrm{~kg} \times \mathrm{m}^{-2}\right)(3$ men and 9 women $)$ and 16 subjects with obesity (BMI $\left.>30 \mathrm{~kg} \times \mathrm{m}^{-2}\right)(3$ men and 13 women $)$. We actively recruited the subjects to participate in the study. Obese subjects were partly recruited from the Outpatient Clinic of the Department of Endocrinology, Diabetology and Internal Medicine, Medical University of Bialystok. Additionally, overweight/obese and control subjects were recruited from the medical staff and students. All participants had no morbid obesity, cardiovascular disease, hypertension, infections and any other serious medical problems and were not taking anti-inflammatory drugs (within previous 3 months) or any drugs known to affect glucose and lipid metabolism. Before entering the study, physical examination was performed. All subjects underwent an oral glucose tolerance test (OGTT) and had normal glucose tolerance according to WHO criteria. All subjects gave written informed consent before entering the study. The study protocol was approved by the Ethics Committee of Medical University of Bialystok, Poland.

\section{Anthropometric measurements}

BMI was calculated as body weight in kilograms divided by height in meters squared $\left(\mathrm{kg} / \mathrm{m}^{2}\right)$. The waist circumference was measured at the smallest circumference between the rib cage and the iliac crest, with the subject in the standing position. Percent of body fat was estimated by bioelectric impedance analysis using the Tanita TBF-511 Body Fat Analyzer (Tanita Corp., Tokyo, Japan).

\section{Insulin sensitivity}

Insulin sensitivity was evaluated by the euglycemic hyperinsulinemic clamp technique as described by DeFronzo et al. [35]. Insulin (Actrapid HM, Novo Nordisk, Copenhagen, Denmark) was given as a primed continuous intravenous infusion for $2 \mathrm{~h}$ at $40 \mathrm{mU} \times \mathrm{m}^{-2} \times \min ^{-1}$, resulting in constant hyperinsulinemia of approximately $75 \mathrm{mU} / \mathrm{l}$. Arterialized blood glucose was obtained every $5 \mathrm{~min}$, and $20 \%$ dextrose $(1.11 \mathrm{~mol} / \mathrm{l})$ infusion was adjusted to maintain plasma glucose levels at $5.0 \mathrm{mmol} / \mathrm{l}$. The glucose infusion rate approached stable values during final $40 \mathrm{~min}$ of the study, and the rate of whole-body glucose uptake ( $M$ value) was calculated as the mean glucose infusion rate from 80 to $120 \mathrm{~min}$, corrected for glucose space and normalized per kilogram of fat-free mass $\left(M_{\mathrm{ffm}}\right)$.

Lipid and glucose oxidation

Whole-body lipid and glucose oxidation rates were measured by indirect calorimetry using the ventilated hood technique (Oxycon Pro, Viasys Healthcare $\mathrm{GmbH}$-Erich Jaeger, Hochberg, Germany) in order to calculate lipid and glucose oxidation from respiratory gas exchange (oxygen 
consumption and carbon dioxide production). The device was calibrated before each test using reference gases. Measurements were taken while the subjects were lying in a supine position at baseline (in the fasting state) and during the last $30 \mathrm{~min}$ of the clamp study. Each study was performed in the thermoneutral environment, after relaxing for $15 \mathrm{~min}$. NOGM was calculated by subtracting the glucose oxidation rate during hyperinsulinemia from whole-body glucose disposal rate. An increase in respiratory exchange ratio (detla RER) in response to insulin was used as a measure metabolic flexibility.

\section{Biochemical analyses}

Fasting blood samples were taken from the antecubital vein before the beginning of the clamp for the determination of serum lipids, sTNFR1, sTNFR2 and adiponectin concentrations. Samples were frozen at $-70^{\circ} \mathrm{C}$ until analyses. Plasma glucose was measured immediately by the enzymatic method using glucose analyzer (YSI 2300 STAT PLUS). Serum insulin was measured with the Medgenix EASIA test (BioSource Europe, Nivelles, Belgium). The minimum detectable concentration was $1.05 \mathrm{pg} / \mathrm{l}$, and the intra-assay and inter-assay coefficients of variation (CVs) were below 5.5 and $10 \%$, respectively. In that method, human and animal proinsulins present no cross-reaction. Serum total and HDL cholesterol and triglycerides (TG) were assessed by the enzymatic methods using commercial kits produced by ANALCO-GBG, Poland. Concentration of LDL cholesterol (LDL-CH) was calculated from Friedewald's formula: LDL-CH $=$ total cholesterol $-\mathrm{TG} /$ 5 - HDL cholesterol (mg/dl).

Serum sTNFR1 and sTNFR2 were determined with the EASIA kits (BioSource Europe). The minimum detectable concentration was $0.05 \mathrm{ng} / \mathrm{ml}$ for sTNFR1 and $0.1 \mathrm{ng} / \mathrm{ml}$ for sTNFR2. The intra-assay and inter-assay CVs for both receptors were below 6.5 and 9\%, respectively. sTNFR1 EASIA does not cross-react with sTNFR2. Serum adiponectin was measured with the RIA Kit (Linco Research, Inc. St. Charles, Missouri, USA) with the detection limit of $1 \mathrm{ng} / \mathrm{ml}$ and with intra-assay and inter-assay CVs below 6.3 and $9.5 \%$, respectively.

\section{Statistical analysis}

The statistics were performed with the STATISTICA 8.0 program (StatSoft, Krakow, Poland). The variables that did not have normal distribution were log-transformed prior to analyses (TG, insulin). The differences between the groups were evaluated with one-way ANOVA and with post hoc Tukey's honestly significant difference test for unequal sample sizes. When overweight and obese subjects were pooled together, the differences between the groups were evaluated with an unpaired Student's $t$ test. The relationships between variables were estimated with the simple and multiple regression analysis. The level of significance was accepted at $P$ value less than 0.05 .

We calculated the sample size on the basis of our previous data on insulin sensitivity (but without indirect calorimetry), serum adiponectin, sTNFR1 and sTNFR2, obtained on the population of about 300 subjects, with similar characteristics to the study group included in the present paper. The results of all these parameters were very similar in these groups. On that basis, the minimal sample size in each group to detect significant differences at $\alpha<0.05$ and $1-\beta>0.80$ was $n=22$ for insulin sensitivity; $n=20$ for serum adiponectin; $n=16$ for sTNFR1; and $n=21$ for sTNFR2.

\section{Results}

The clinical characteristics of the studied groups are shown in Table 1. Obese subjects had lower insulin sensitivity and serum adiponectin concentration $(P=0.003$ and $P=0.007$, respectively) versus lean subject. Serum levels of sTNFR1 and sTNFR2 were higher in the obese group $(P<0.001$ and $P=0.008$, respectively) versus lean group (Table 1).

Fasting rates of lipid and glucose oxidation did not differ between studied groups. Obese subject had higher rate of lipid oxidation during the clamp $(P=0.003)$ and lower NOGM and metabolic flexibility (both $P=0.01$ ) versus lean group (Table 2).

Additionally, because there were no differences between overweight and obese subjects in insulin sensitivity, serum adiponectin, sTNFR1 and sTNFR2, we calculated data for overweight and obese subjects pooled together. The results of the research showed that obese/overweight subjects had lower insulin sensitivity and serum adiponectin concentration (both $P<0.001$ ). Serum levels of sTNFR1 and sTNFR2 were higher in these group $(P<0.001$ and $P=0.001$, respectively).

Fasting rates of lipid and glucose oxidation also did not differ between lean and obese/overweight groups. Obese/ overweight group had higher rate of lipid oxidation during the clamp $(P=0.0005)$ and lower rate of glucose oxidation during hyperinsulinemia $(P=0.01)$, lower NOGM and metabolic flexibility $(P=0.004$ and $P=0.003$, respectively).

Insulin sensitivity was positively related to serum adiponectin concentration $(r=0.49, P<0.001)$ and negatively related to STNFR1 and sTNFR2 $(r=-0.40, P=$ $0.004, r=-0.52, P<0.001$, respectively). Adiponectin was related to the rate of glucose $(r=0.47, P<0.001)$ 
Table 1 Clinical and biochemical characteristics of the studied groups

\begin{tabular}{|c|c|c|c|c|}
\hline & Lean subjects $(n=25)$ & Overweight subjects $(n=12)$ & Obese subjects $(n=16)$ & $P$ \\
\hline Age (year) & $25.1 \pm 5.3$ & $25 \pm 5.3$ & $28.3 \pm 7.9$ & 0.23 \\
\hline $\mathrm{M} / \mathrm{F}$ & $6 / 19$ & $3 / 9$ & $3 / 13$ & \\
\hline BMI $\left(\mathrm{kg} / \mathrm{m}^{2}\right)$ & $21.64 \pm 2.03$ & $27.11 \pm 1.77$ & $33.89 \pm 2.96$ & $<0.0001$ \\
\hline Waist girth $(\mathrm{cm})$ & $74.2 \pm 6.1$ & $85.3 \pm 5.9^{*}, * * *$ & $104.1 \pm 6.9 * *$ & $<0.0001$ \\
\hline Body fat $(\%)$ & $23.2 \pm 6.6$ & $30.4 \pm 7.5^{* * *}$ & $42.9 \pm 10.7^{* *}$ & $<0.0001$ \\
\hline Total cholesterol (mg/dl) & $172.7 \pm 31.2$ & $176.2 \pm 39.2$ & $176.9 \pm 40.2$ & 0.92 \\
\hline Serum TG (mg/dl) & $71.3 \pm 32.8$ & $85.0 \pm 32.3$ & $179.0 \pm 226.2^{* *}$ & 0.03 \\
\hline HDL cholesterol (mg/dl) & $60.3 \pm 10.5$ & $56.1 \pm 6.2$ & $54.4 \pm 9.4$ & 0.13 \\
\hline LDL cholesterol (mg/dl) & $98.1 \pm 31.3$ & $98.5 \pm 34.1$ & $88.0 \pm 23.8$ & 0.58 \\
\hline Fasting glucose $(\mathrm{mg} / \mathrm{dl})$ & $80.4 \pm 7.4$ & $84.3 \pm 6.8$ & $83.4 \pm 9.6$ & 0.29 \\
\hline Postload glucose (mg/dl) & $75.3 \pm 15.8$ & $87.8 \pm 16.1$ & $96.2 \pm 21.8^{* *}$ & 0.002 \\
\hline Fasting insulin $(\mu \mathrm{IU} / \mathrm{ml})$ & $11.9 \pm 5.2$ & $12.4 \pm 4.1 * * *$ & $22.3 \pm 13.4 * *$ & 0.001 \\
\hline Postload insulin $(\mu \mathrm{IU} / \mathrm{ml})$ & $30.9 \pm 19.0$ & $47.7 \pm 36.3$ & $95.4 \pm 78.2 * *$ & $<0.0001$ \\
\hline$M\left(\mathrm{mg} \times \mathrm{kg}_{\mathrm{ffm}}^{-1} \times \min ^{-1}\right)$ & $11.16 \pm 3.07$ & $9.01 \pm 2.61$ & $7.21 \pm 3.95 * *$ & 0.001 \\
\hline Serum adiponectin $(\mu \mathrm{g} / \mathrm{ml})$ & $16.2 \pm 4.7$ & $12.1 \pm 5.4$ & $11.2 \pm 3.2^{* *}$ & 0.001 \\
\hline Serum sTNFR1 (ng/ml) & $1.78 \pm 0.29$ & $2.02 \pm 0.29$ & $2.27 \pm 0.35 * *$ & $<0.0001$ \\
\hline Serum sTNFR2 (ng/ml) & $3.80 \pm 0.88$ & $4.46 \pm 0.89$ & $4.86 \pm 0.91 * *$ & 0.002 \\
\hline
\end{tabular}

Data are presented as mean $\pm \mathrm{SD}$

$M / F$ Male/female, BMI Body mass index, OGTT Oral glucose tolerance test, $M$ Whole-body glucose uptake normalized per kg of fat-free mass, sTNFR1 Soluble TNF $\alpha$ receptor 1, sTNFR2 Soluble TNF $\alpha$ receptor 2

* $P<0.05$ in overweight versus lean subjects

** $P<0.05$ in obese versus lean subjects

*** $P<0.05$ in overweight versus obese subjects

Table 2 Respiratory exchange ratio, nutrient oxidation rate, NOGM and metabolic flexibility before and during clamp in lean and obese subjects

\begin{tabular}{|c|c|c|c|c|}
\hline & Lean subjects $(n=25)$ & Overweight subjects $(n=12)$ & Obese subjects $(n=16)$ & $P$ \\
\hline RER-basal & $0.80 \pm 004$ & $0.80 \pm 0.04$ & $0.82 \pm 0.06$ & 0.63 \\
\hline RER-clamp & $0.86 \pm 0.04$ & $0.82 \pm 0.05$ & $0.81 \pm 0.04^{*}$ & 0.01 \\
\hline COx-basal $\left(\mathrm{mg} \times \mathrm{kg}_{\mathrm{ffm}}^{-1} \times \min ^{-1}\right)$ & $1.35 \pm 0.77$ & $1.32 \pm 0.68$ & $1.81 \pm 1.18$ & 0.21 \\
\hline LOx-basal $\left(\mathrm{mg} \times \mathrm{kg}_{\mathrm{ffm}}^{-1} \times \min ^{-1}\right)$ & $1.03 \pm 0.35$ & $1.12 \pm 0.32$ & $1.19 \pm 0.60$ & 0.47 \\
\hline COx-clamp $\left(\mathrm{mg} \times \mathrm{kg}_{\mathrm{ffm}}^{-1} \times \min ^{-1}\right)$ & $2.32 \pm 0.86$ & $1.76 \pm 0.82$ & $1.66 \pm 0.85$ & 0.03 \\
\hline LOx-clamp $\left(\mathrm{mg} \times \mathrm{kg}_{\mathrm{ffm}}^{-1} \times \mathrm{min}^{-1}\right)$ & $0.69 \pm 0.36$ & $0.99 \pm 0.38$ & $1.18 \pm 0.45^{*}$ & 0.001 \\
\hline $\operatorname{NOGM}\left(\mathrm{mg} \times \mathrm{kg}_{\mathrm{ffm}}^{-1} \times \mathrm{min}^{-1}\right)$ & $8.84 \pm 3.0$ & $7.25 \pm 2.35$ & $5.55 \pm 3.75^{*}$ & 0.007 \\
\hline Delta RER & $0.05 \pm 0.05$ & $0.02 \pm 0.05$ & $-0.004 \pm 0.05^{*}$ & 0.006 \\
\hline
\end{tabular}

Data are presented as mean $\pm \mathrm{SD}$

RER1 Respiratory exchange ratio before clamp, RER2 Respiratory exchange ratio during clamp, REE1 Resting energy expenditure before clamp, REE2 Resting energy expenditure during clamp, COx-basal Rate of glucose oxidation in the basal state, LOx-basal Rate of lipid oxidation in the basal state, COx-clamp Rate of glucose oxidation during hyperinsulinemia, LOx-clamp Rate of lipid oxidation during hyperinsulinemia, NOGM Non-oxidative glucose metabolism, delta RER Change in respiratory exchange ratio in response to hyperinsulinemia

$* P<0.05$ in obese versus lean subjects

and lipid $(r=-0.40, P=0.003)$ oxidation during the clamp (Fig. 1a, b). We also found positive correlation between adiponectin and RER during the clamp $(r=0.43$, $P=0.001)$ and with NOGM $(r=0.41, P=0.002)$ and metabolic flexibility $(r=0.36, \quad P=0.007)$. Serum sTNFR1 concentration was associated with the rate of glucose $\quad(r=-0.45, \quad P=0.001) \quad$ (Fig. 1c) and lipid $(r=0.52, P<0.001)$ (Fig. 1d) oxidation during hyperinsulinemia and also with NOGM $(r=-0.31$, $P=0.02)$ and metabolic flexibility $(r=-0.47, \quad P<$ 0.001). Similarly, serum sTNFR2 correlated with the rate of glucose $(r=-0.51, P<0.001)$ and lipid $(r=0.46$, 

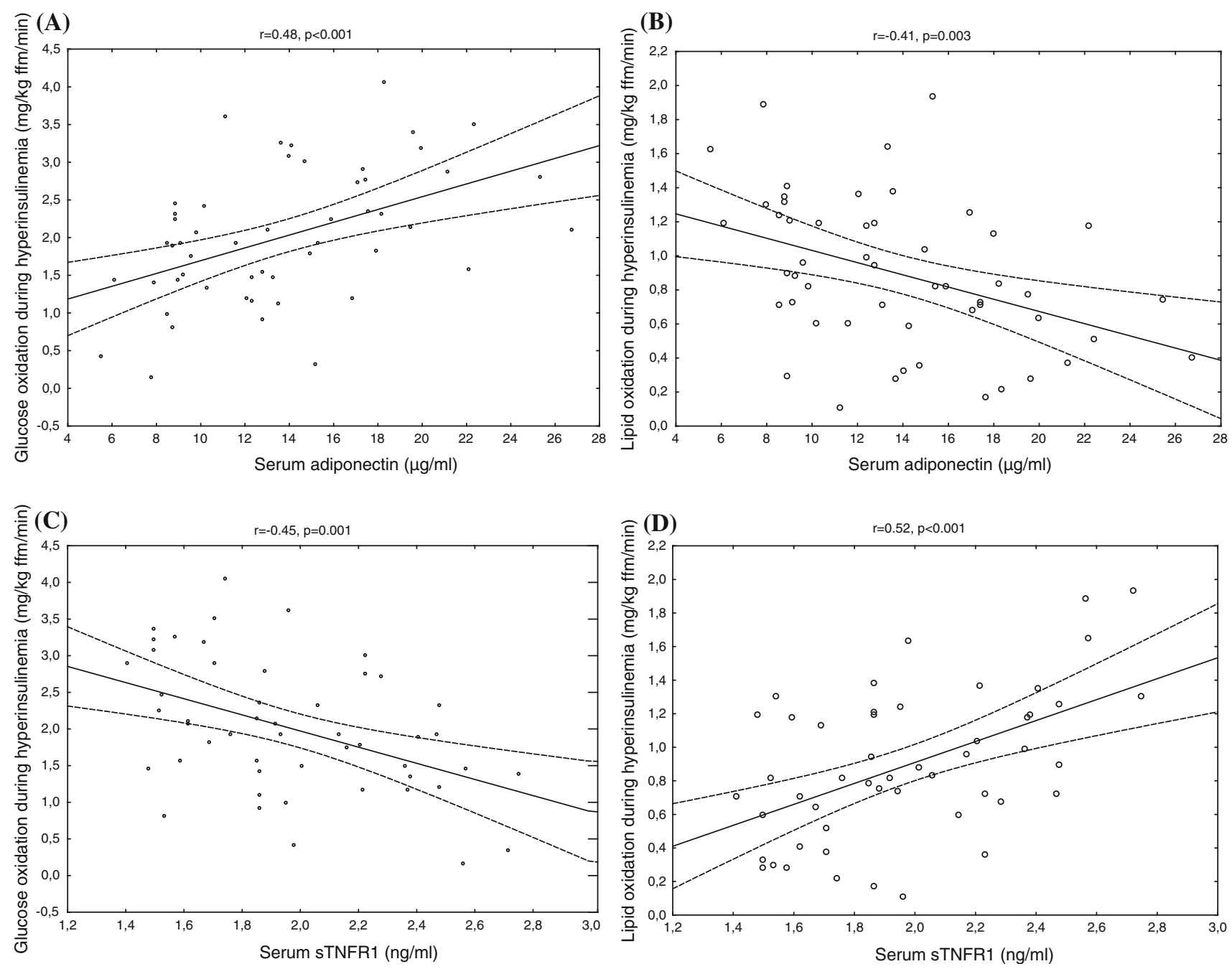

Fig. 1 Relationship between serum adiponectin and glucose oxidation (a) and lipid oxidation (b) during hyperinsulinemia and relationship between serum sTNFR1 and glucose oxidation (c) and lipid oxidation (d) during the clamp in the entire study group $(n=53)$

$P=0.001)$ oxidation and with NOGM $(r=-0.43, P=$ $0.002)$ and metabolic flexibility $(r=-0.51, P<0.001)$.

We observed negative correlation between waist circumference and adiponectin $(r=-0.39, P=0.003)$ and positive correlation between waist circumference and sTNFR1 and sTNFR2 $(r=0.58, P<0.0001 ; r=0.50$, $P<0.0001$, respectively).

In multiple regression analysis, we observed that the relationship between $\mathrm{M}$ and adiponectin $(\beta=0.31$; $P=0.02$ ) was independent of age, gender and waist circumference (Table 3). We observed also that the relationships between glucose oxidation during the clamp and sTNFR1 $(\beta=-0.34 ; P=0.03)$ and adiponectin $(\beta=0.38$; $P=0.004)$ were independent of each other and also independent of age, gender and waist circumference (Table 4). Similar results were obtained when sTNFR2 was entered instead of sTNFR1 into the regression model (adiponectin, $\beta=0.30, \quad P=0.02 ; \quad$ sTNFR $2, \quad \beta=-0.48 ; \quad P=0.004)$
(Table 4). Correlations between lipid oxidation during the clamp and sTNFR1 $(\beta=0.41 ; P=0.008)$ (Table 4) and sTNFR2 $(\beta=0.41 ; P=0.01)$ (Table 5) were independent of adiponectin, age and waist circumference.

\section{Discussion}

In the present study, we investigated serum adiponectin, sTNFR1 and sTNFR2 concentrations in relation to lipid and glucose metabolism. We showed decreased serum adiponectin concentration in obese patients and positive correlation between this cytokine and insulin sensitivity. There is growing evidence that adiponectin function is closely related to the pathogenesis of insulin resistance [11, 16-18, 21, 39, 40]. In our study, serum adiponectin concentration was negatively correlated with the rate of lipid oxidation during hyperinsulinemia and positively with 
Table 3 Multiple regression analysis of insulin sensitivity $(M)$ and age, gender, WC and adiponectin

\begin{tabular}{lrl}
\hline Variable & \multicolumn{1}{l}{$M$} & \\
\cline { 2 - 3 } & \multicolumn{1}{c}{$B$} & $P$ value \\
\hline Age & -0.096 & 0.411 \\
Gender & 0.203 & 0.082 \\
WC & -0.343 & 0.009 \\
Adiponectin & 0.312 & 0.016 \\
\hline
\end{tabular}

$\overline{W C}$ Waist circumference, $M$ Whole-body glucose uptake normalized per $\mathrm{kg}$ of fat-free mass

Table 4 Multiple regression analysis of lipid and glucose oxidation during the metabolic clamp and age, gender, WC, adiponectin and sTNFR1

\begin{tabular}{lccccc}
\hline Variable & \multicolumn{2}{l}{ LOx-clamp } & & \multicolumn{2}{l}{ COx-clamp } \\
\cline { 2 - 3 } \cline { 6 - 7 } & $B$ & $P$ value & & $B$ & $P$ value \\
\hline Age & 0.0009 & 0.993 & & -0.058 & 0.635 \\
Gender & 0.264 & 0.037 & & -0.206 & 0.111 \\
WC & 0.154 & 0.324 & & -0.044 & 0.781 \\
Adiponectin & -0.246 & 0.055 & & 0.388 & 0.004 \\
sTNFR1 & 0.416 & 0.008 & & -0.346 & 0.031 \\
\hline
\end{tabular}

WC Waist circumference, sTNFR1 Soluble TNF $\alpha$ receptor 1, COxclamp Rate of glucose oxidation during hyperinsulinemia, LOx-clamp Rate of lipid oxidation during hyperinsulinemia

Table 5 Multiple regression analysis of lipid and glucose oxidation during the metabolic clamp and age, gender, WC, adiponectin and sTNFR2

\begin{tabular}{lrlrrr}
\hline Variable & \multicolumn{2}{l}{ LOx-clamp } & & \multicolumn{2}{c}{ COx-clamp } \\
\cline { 2 - 3 } \cline { 6 - 7 } & \multicolumn{1}{c}{$B$} & $P$ value & & \multicolumn{1}{l}{$B$} & $P$ value \\
\hline Age & -0.058 & 0.629 & & 0.004 & 0.968 \\
Gender & 0.315 & 0.027 & & -0.307 & 0.028 \\
WC & 0.239 & 0.119 & & -0.067 & 0.652 \\
Adiponectin & -0.178 & 0.185 & & 0.297 & 0.027 \\
sTNFR2 & 0.406 & 0.018 & & -0.484 & 0.004 \\
\hline
\end{tabular}

WC Waist circumference, sTNFR2 Soluble TNF $\alpha$ receptor 2, COxclamp Rate of glucose oxidation during hyperinsulinemia, LOx-clamp Rate of lipid oxidation during hyperinsulinemia

NOGM and the rate of glucose oxidation during the clamp. These results suggest that high serum adiponectin concentration protects from developing insulin resistance by stimulating glucose oxidation and inhibiting lipid oxidation during hyperinsulinemia and increasing NOGM. These data are in agreement with Salmenniemi et al. who reported similar results in offspring of type 2 diabetic patients [24]. Another group reported no significant correlation between serum adiponectin level and substrates oxidation, either before or during the clamp [8]. However, these data were obtained mostly from type 2 diabetic subjects, older than in the present study. Højlund et al. showed that reduced serum adiponectin concentration may contribute to an impaired insulin activation of glycogen synthase in the skeletal muscle of patients with type 2 diabetes [21]. It was also reported that adiponectin increases GLUT4 translocation and glucose uptake but reduces glycogen synthesis in rat skeletal muscle [25] presumably via activation of AMP kinase [23, 25].

Another factors that could modulate insulin sensitivity and substrates metabolism are soluble TNF- $\alpha$ receptors. In the present report, we showed an increase in serum sTNFR1 and sTNFR2 concentration in obese patients in comparison with the lean subjects. We also observed negative correlation between insulin sensitivity and serum sTNFR1 and sTNFR2 concentrations. These findings are consistent with our previous reports $[11,13,38]$. Our data indicate that a soluble TNF- $\alpha$ receptors are associated with insulin resistance through its relationship with substrate oxidation in hyperinsulinemic condition and NOGM. Hotamisligil et al. reported that TNF- $\alpha$ is an important mediator of insulin resistance in obesity through its ability to decrease the tyrosine kinase activity of the insulin receptor [41]. TNF- $\alpha$ has been shown to inhibit insulinstimulated GLUT4 translocation and glucose uptake through inhibition of insulin signaling [9]. In experimental study, Bruce et al. showed that TNF- $\alpha$ had no effect on lipid oxidation but increased fatty acid incorporation into DAG, which may be involved in the development of $\mathrm{TNF}-\alpha$-induced insulin resistance in skeletal muscle [42].

Although there are studies reporting the impact of TNF- $\alpha$ system on substrate oxidation, to the best of our knowledge, this is the first data to report such associations in human studies in vivo. Additionally, as mentioned in the Introduction, the human data regarding the association between adiponectin and substrate oxidation are controversial and our study provides the first results in this field obtained in young and apparently healthy population, free of potential multiple confounding factors.

The possible limitations of our study include relatively small number of male subjects, which can affect the results of gender and also limited number of subjects in overweight and obese groups. However, we were able to detect significant differences in insulin sensitivity and inflammatory markers between the groups when the overweight/obese subjects were pooled together and also between lean and obese subjects in one-way ANOVA with post hoc Tukey's test. Additionally, in the regression models, we observed that some of the relationships between inflammatory markers and substrate oxidation were independent of age and the measure of visceral adiposity (waist circumference).

Our data showed that soluble TNF- $\alpha$ receptors and adiponectin correlated in inverse manner with insulin 
sensitivity and they have multiple effect on substrates metabolism during hyperinsulinemia, NOGM and metabolic flexibility.

The obtained results suggest that soluble TNF- $\alpha$ receptors and adiponectin have multiple effects on glucose and lipid metabolism in obesity.

Acknowledgments This work was supported by the Grant from Medical University of Bialystok, Poland number 3-50706L.

Conflict of interest The authors have not declared any conflicts of interest.

Open Access This article is distributed under the terms of the Creative Commons Attribution Noncommercial License which permits any noncommercial use, distribution, and reproduction in any medium, provided the original author(s) and source are credited.

\section{References}

1. Fernández-Real J, Ricart W (2003) Insulin resistance and chronic cardiovascular inflammatory syndrome. Endocr Rev 24:278-301

2. Meshkani R, Zargari M, Larijani B (2010) The relationship between uric acid and metabolic syndrome in normal glucose tolerance and normal fasting glucose subjects. Acta Diabetol (online first)

3. Chokkalingam K, Jewell K, Norton L et al (2007) High-fat/lowcarbohydrate diet reduces insulin-stimulated carbohydrate oxidation but stimulates nonoxidative glucose disposal in humans: an important role for skeletal muscle pyruvate dehydrogenase kinase 4. J Clin Endocrinol Metab 92:284-292

4. Koska J, Ortega E, Bogardus C, Krakoff J, Bunt J (2007) The effect of insulin on net lipid oxidation predicts worsening of insulin resistance and development of type 2 diabetes mellitus. Am J Physiol Endocrinol Metab 293:E264-E269

5. Salmenniemi U, Ruotsalainen E, Pihlajamäki J et al (2004) Multiple abnormalities in glucose and energy metabolism and coordinated changes in levels of adiponectin, cytokines, and adhesion molecules in subjects with metabolic syndrome. Circulation 110:3842-3848

6. Golay A, DeFronzo R, Ferrannini E et al (1998) Oxidative and non-oxidative glucose metabolism in non-obese type 2 (noninsulin-dependent) diabetic patients. Diabetologia 31:585-591

7. Haugaard S, Andersen O, Madsbad S et al (2005) Skeletal muscle insulin signaling defects downstream of phosphatidylinositol 3-kinase at the level of Akt are associated with impaired nonoxidative glucose disposal in HIV lipodystrophy. Diabetes 54:3474-3483

8. Yokoyama H, Emoto M, Mori K et al (2006) Plasma adiponectin level is associated with insulin-stimulated nonoxidative glucose disposal. J Clin Endocrinol Metab 91:290-294

9. de Alvaro C, Teruel T, Hernandez R, Lorenzo M (2004) Tumor necrosis factor alpha produces insulin resistance in skeletal muscle by activation of inhibitor kappaB kinase in a p38 MAPKdependent manner. J Biol Chem 279:17070-17078

10. Aderka D, Engelmann H, Maor Y, Brakebusch C, Wallach D (1992) Stabilization of the bioactivity of tumor necrosis factor by its soluble receptors. J Exp Med 175:323-329

11. Kowalska I, Straczkowski M, Nikołajuk A, Krukowska A, Kinalska I, Górska M (2006) Plasma adiponectin concentration and tumor necrosis factor-alpha system activity in lean non-diabetic offspring of type 2 diabetic subjects. Eur J Endocrinol 154:319-324

12. Straczkowski M, Kowalska I, Nikolajuk A et al (2006) Plasma levels of soluble tumor necrosis factor-alpha receptors are related to total and LDL-cholesterol in lean, but not in obese subjects. Cardiovasc Diabetol 5:14

13. Straczkowski M, Kowalska I, Stepien A, Dzienis-Straczkowska S, Szelachowska M, Kinalska I (2002) Increased plasma-soluble tumor necrosis factor-alpha receptor 2 level in lean nondiabetic offspring of type 2 diabetic subjects. Diabetes Care 25:18241828

14. Hotamisligil G, Budavari A, Murray D, Spiegelman B (1994) Reduced tyrosine kinase activity of the insulin receptor in obesity-diabetes. Central role of tumor necrosis factor-alpha. J Clin Invest 94:1543-1549

15. Baratta R, Amato S, Degano C et al (2004) Adiponectin relationship with lipid metabolism is independent of body fat mass: evidence from both cross-sectional and intervention studies. J Clin Endocrinol Metab 89:2665-2671

16. Arita Y, Kihara S, Ouchi N et al (1999) Paradoxical decrease of an adipose-specific protein, adiponectin, in obesity. Biochem Biophys Res Commun 257:79-83

17. Hotta K, Funahashi T, Arita Y et al (2000) Plasma concentrations of a novel, adipose-specific protein, adiponectin, in type 2 diabetic patients. Arterioscler Thromb Vasc Biol 20:1595-1599

18. Hara K, Boutin P, Mori Y et al (2002) Genetic variation in the gene encoding adiponectin is associated with an increased risk of type 2 diabetes in the Japanese population. Diabetes 51:536-540

19. King G, Deemer S, Thompson D (2010) Adiponectin is associated with risk of the metabolic syndrome and insulin resistance in women. Acta Diabetol (online first)

20. Su SC, Pei D, Hsieh C, Hsiao F, Wu C, Hung Y (2010) Circulating pro-inflammatory cytokines and adiponectin in young men with type 2 diabetes. Acta Diabetol (online first)

21. Højlund K, Frystyk J, Levin K, Flyvbjerg A, Wojtaszewski J, Beck-Nielsen H (2006) Reduced plasma adiponectin concentrations may contribute to impaired insulin activation of glycogen synthase in skeletal muscle of patients with type 2 diabetes. Diabetologia 49:1283-1291

22. Storgaard H, Poulsen P, Ling C, Groop L, Vaag A (2007) Relationships of plasma adiponectin level and adiponectin receptors 1 and 2 gene expression to insulin sensitivity and glucose and fat metabolism in monozygotic and dizygotic twins. J Clin Endocrinol Metab 92:2835-2839

23. Yamauchi T, Kamon J, Minokoshi Y et al (2002) Adiponectin stimulates glucose utilization and fatty-acid oxidation by activating AMP-activated protein kinase. Nat Med 8:1288-1295

24. Salmenniemi U, Zacharova J, Ruotsalainen E et al (2005) Association of adiponectin level and variants in the adiponectin gene with glucose metabolism, energy expenditure, and cytokines in offspring of type 2 diabetic patients. J Clin Endocrinol Metab 90:4216-4223

25. Ceddia R, Somwar R, Maida A, Fang X, Bikopoulos G, Sweeney G (2005) Globular adiponectin increases GLUT4 translocation and glucose uptake but reduces glycogen synthesis in rat skeletal muscle cells. Diabetologia 48:132-139

26. Hulstrøm V, Højlund K, Vinten J, Beck-Nielsen H, Levin K (2008) Adiponectin and its response to thiazolidinediones are associated with insulin-mediated glucose metabolism in type 2 diabetic patients and their first-degree relatives. Diabetes Obes Metab 10:1019-1028

27. Yin C, Long Q, Lei T et al (2009) Lipid accumulation mediated by adiponectin in C2C12 myogenesis. BMB Rep 42:667-672

28. Sparks L, Ukropcova B, Smith J et al (2009) Relation of adipose tissue to metabolic flexibility. Diabetes Res Clin Pract 83:32-43 
29. Peraldi P, Hotamisligil G, Buurman W, White M, Spiegelman B (1996) Tumor necrosis factor (TNF)-alpha inhibits insulin signaling through stimulation of the p55 TNF receptor and activation of sphingomyelinase. J Biol Chem 271:13018-13022

30. Cho S, Park P, Shin E, Lee J, Chang H, Lee T (2009) Proteomic analysis of mitochondrial proteins of basal and lipolytically (isoproterenol and TNF-alpha)-stimulated adipocytes. J Cell Biochem 106:257-266

31. Pellieux C, Montessuit C, Papageorgiou I, Lerch R (2009) Angiotensin II downregulates the fatty acid oxidation pathway in adult rat cardiomyocytes via release of tumour necrosis factoralpha. Cardiovasc Res 82:341-350

32. Pamir N, McMillen T, Kaiyala K, Schwartz M, LeBoeuf R (2009) Receptors for tumor necrosis factor-alpha play a protective role against obesity and alter adipose tissue macrophage status. Endocrinology 150:4124-4134

33. Plomgaard P, Fischer C, Ibfelt T, Pedersen B, van Hall G (2008) Tumor necrosis factor-alpha modulates human in vivo lipolysis. J Clin Endocrinol Metab 93:543-549

34. Palomer X, Alvarez-Guardia D, Rodríguez-Calvo R et al (2009) TNF-alpha reduces PGC-1alpha expression through NF-kappaB and p38 MAPK leading to increased glucose oxidation in a human cardiac cell model. Cardiovasc Res 81:703-712

35. DeFronzo R, Tobin J, Andres R (1979) Glucose clamp technique: a method for quantifying insulin secretion and resistance. Am $\mathrm{J}$ Physiol 237:E214-E223
36. Brun JF et al. (2010) Assessment of insulin sensitivity (SI) and glucose effectiveness (SG) from a standardized hyperglucidic breakfast test in type 2 diabetics exhibiting various levels of insulin resistance. Acta Diabetol (online first)

37. Ruan $\mathrm{W}$ et al (2010) Insulin-like growth factor binding protein: a possible marker for the metabolic syndrome? Diabetol 47:5-14

38. Dzienis-Straczkowska S, Straczkowski M, Szelachowska M, Stepien A, Kowalska I, Kinalska I (2003) Soluble tumor necrosis factor-alpha receptors in young obese subjects with normal and impaired glucose tolerance. Diabetes Care 26:875-880

39. Ouchi N, Kihara S, Arita Y et al (2000) Adiponectin, an adipocyte-derived plasma protein, inhibits endothelial NF-kappaB signaling through a cAMP-dependent pathway. Circulation 102: 1296-1301

40. Yamauchi T, Kamon J, Waki $\mathrm{H}$ et al (2001) The fat-derived hormone adiponectin reverses insulin resistance associated with both lipoatrophy and obesity. Nat Med 7:941-946

41. Hotamisligil G, Peraldi P, Budavari A, Ellis R, White M, Spiegelman B (1996) IRS-1-mediated inhibition of insulin receptor tyrosine kinase activity in TNF-alpha- and obesityinduced insulin resistance. Science 271:665-668

42. Bruce C, Dyck D (2004) Cytokine regulation of skeletal muscle fatty acid metabolism: effect of interleukin-6 and tumor necrosis factor-alpha. Am J Physiol Endocrinol Metab 287:E616-E621 